\title{
Climate change, water resources, and the politics of adaptation in the Middle East and North Africa
}

\author{
Jeannie Sowers • Avner Vengosh • Erika Weinthal
}

Received: 18 May 2009 / Accepted: 15 January 2010 / Published online: 23 April 2010

(C) Springer Science+Business Media B.V. 2010

\begin{abstract}
Through an examination of global climate change models combined with hydrological data on deteriorating water quality in the Middle East and North Africa (MENA), we elucidate the ways in which the MENA countries are vulnerable to climate-induced impacts on water resources. Adaptive governance strategies, however, remain a low priority for political leaderships in the MENA region. To date, most MENA governments have concentrated the bulk of their resources on largescale supply side projects such as desalination, dam construction, inter-basin water transfers, tapping fossil groundwater aquifers, and importing virtual water. Because managing water demand, improving the efficiency of water use, and promoting conservation will be key ingredients in responding to climate-induced impacts on the water sector, we analyze the political, economic, and institutional drivers that have shaped governance responses. While the scholarly literature emphasizes the importance of social capital to adaptive governance, we find that many political leaders and water experts in the MENA rarely engage societal actors in considering water risks. We conclude that the key capacities for adaptive governance to water scarcity in MENA are underdeveloped.
\end{abstract}

The authors share equal responsibility for the content and analysis herein.

\section{J. Sowers}

Department of Political Science, University of New Hampshire,

Durham, NH 03824, USA

e-mail: Jeannie.Sowers@unh.edu

\section{A. Vengosh}

Division of Earth and Ocean Sciences, Nicholas School of the Environment,

Duke University, Durham, NC 27708, USA

e-mail: vengosh@duke.edu

E. Weinthal $(\varangle)$

Division of Environmental Sciences and Policy,

Nicholas School of the Environment, Duke University, Durham, NC 27708, USA

e-mail: weinthal@duke.edu 


\section{Introduction}

As a largely arid region, the Middle East and North Africa (MENA) is particularly vulnerable to climate-induced impacts on water resources, yet promoting adaptive governance strategies to deal with increased hydrological risk remains a low priority for political leaderships. It is increasingly clear that climate change will interact with other social, economic and political variables to exacerbate social and political vulnerabilities. In general, climate change acts as a "threat multiplier" for vulnerable countries and populations (e.g. Evans 2008a, b; UNDP 2007/2008). ${ }^{1}$ Yet climate impacts will not be equally distributed, and much will depend upon national resources and adaptive capacities. In this article, we delineate the expected impacts of climate change on water resources in the MENA and analyze the political, economic, and institutional drivers that have shaped governance responses.

Climate change coupled with demographic growth will profoundly affect the availability and quality of water resources in the MENA region (Conway and Hulme 1996; Suppan et al. 2008; Alpert et al. 2008; Sánchez et al. 2004; Milly et al. 2005; Gao and Giorgi 2008; Evans 2008a, b, 2009). Acceleration in the hydrological cycle will likely make droughts longer and rainfall events more variable and intense, raising probabilities of flooding and desertification. As we show, these impacts on the water sector, combined with deteriorating water quality, rising sea levels, and demographic growth, are already evident in much of the MENA. Over-extraction of groundwater aquifers and their contamination, salinization of agricultural land, and urban water shortages, we find, have sparked some policy reforms and adaptive measures, albeit under conditions of crisis management.

For our purposes, adaptation means developing institutional and political capacities to ensure adequate water supply and water quality in the face of intensifying risks from climate-related impacts. ${ }^{2}$ One key element of adaptation is diversification of water management strategies; another is ensuring equitable access for vulnerable populations. Most MENA countries already employ a variety of supply-side measures, including dams, water transfer schemes, desalination, reuse of treated wastewater, and procuring 'virtual water' (Allan 2001) through imports. Water experts in the region, in concert with international institutions, increasingly advocate demand management to promote conservation and increase efficiency. This has prompted experiments in public-private partnerships, user associations, and privatization of water services. Similarly, water experts have embraced integrated water resource management (hereafter, IWRM), interpreted by regional water experts as enhancing cross-sectoral planning and coordination by government ministries. Yet in practice, MENA governments continue to focus most of their resources on large-scale supply side projects, increasingly tapping fossil groundwater aquifers and building desalination plants.

As we argue, water resource planning in the MENA does not adequately address issues of equity in water access, linkages to population growth, or a more inclusionary

\footnotetext{
${ }^{1}$ For a discussion of meanings of vulnerability, see Smit and Wandel (2006).

${ }^{2}$ Smit and Wandel (2006) and Nelson et al. (2007) offer good overviews of adaptation within the climate change literature.
} 
role for political mobilization around resource access. Aggregate population growth, for instance, is treated as a driver of water scarcity, prompting states to allocate ever greater resources to procure more supplies. Much of the water 'found' through water diversions, desalination, and groundwater extraction, however, is consumed by privileged users, whether in cities or larger agricultural operations. Poor and marginalized communities must often pay for water from private providers at rates many times those of publicly supplied consumers.

Similarly, governments and water experts in the MENA have thus far seen little reason to seriously engage societal actors in considering water risks. Legacies of centralized systems of planning, taxation, and revenue distribution have rendered multi-scalar governance mechanisms weak in terms of organizational capacities and integration with local constituencies. Cities, provinces, and other subnational levels of government are not significant players in identifying vulnerable populations or planning for increased hydrological risk. Voluntary associations are tightly regulated in most of the authoritarian states of the region, while a variety of communal services, charities, and forms of Islamist collective mobilization are often seen as threat to state integrity and legitimacy. While the scholarly literature emphasizes the importance of social capital to adaptive governance (e.g. Adger 2003; Dietz et al. 2003; Pelling and High 2005), many authoritarian regimes in MENA have, nonetheless, sought to weaken, disorganize, and co-opt social mobilization and organization (e.g. Fahmy 2002; Kassem 2004 for the Egyptian case). The result, we find, is that key capacities for adaptive governance to water scarcity are not promoted; rather than engaging societal actors, leaders continue to rely largely upon technical solutions to augment supply.

In order to explicate why the key capacities for adaptive governance to water scarcity in MENA are underdeveloped, the rest of the article proceeds as follows. In Section 2, we provide an overview of the vulnerability to climate change within MENA. Sections 3 to 6 then discuss the main impacts of climate change on precipitation, coastal water resources and agriculture, with a focus on how rapid demographic growth will exacerbate water availability in the MENA. Finally, in Sections 7 to 9, we elucidate the political, social and economic constraints that the MENA countries face in effectively devising policy responses for adaptation and identify options for them to consider seriously their vulnerabilities.

\section{Vulnerability to climate change within the MENA region}

It is ever more apparent, as the Stern Review noted, that the "the poorest countries and populations" will bear the greatest costs of climate change (Stern 2006, p. vii). The adverse impacts of global climate change represent a massive transfer of environmental harm to vulnerable regions and developing countries that has few historical parallels. Countries and populations that only marginally participated in the long-term accumulation of greenhouse gas emissions in the atmosphere will bear the brunt of the costs of water-related adaptation to climate change. Many developing countries already face grave structural economic problems, governance challenges, and ecosystem threats (Lemos and Agrawal 2006; Adger et al. 2003).

As a region, the MENA is characterized by great disparities in wealth and differently structured economies. One of the most significant divides has been 
between those countries that can afford to access or create new sources of water, and those that face grave financial difficulties in trying to do so. The oil-exporting states, including Saudi Arabia, the small city-states and emirates of the Gulf, and Libya, exceeded their renewable freshwater resources some decades ago and rely on a combination of desalination, reused wastewater, and exploration of fossil groundwater to meet increasing demands. Israel, likewise, is mainly focusing on desalination and reuse of wastewater. All of these countries also consume more water per capita than poorer countries. The other states in the region fall mainly into two groups: those endowed with more significant surface freshwater resources (Turkey, Egypt, Sudan, Iran, Iraq, Lebanon) and those who rely on groundwater but struggle to mobilize the kind of investments necessary to secure 'new' large-scale water sources (Jordan, Yemen, Tunisia, Algeria). Some countries (Morocco, Syria) are based on both surface water and groundwater resources.

Many citizens of the MENA region already cope with inadequate, polluted water supplies. Particularly in informal urban areas, states have shifted the burden of accessing water onto families and individuals, who must arrange for private and expensive water deliveries (e.g. Trottier 2000). Others endure water rationing, where water is provided for only a few hours a day. For example, many houses in Jordan and the West Bank have water storage tanks on the roof to collect water for later use. Poor neighborhoods also access water through illegal connections and direct use of irrigation or drainage canals.

The region long ago exceeded the water resources necessary to supply its population with food (Allan 1997). The quiet solution was importing food, which Allen argued constituted 'virtual water' (ibid). Addressing water scarcity by importing virtual water has until recently lessened political urgency around water issues (Allan 2001). Results from a 2006 pan-Arab public opinion survey noted that "[i]t was remarkable that a relatively high percentage of respondents from countries poor in natural fresh water resources, and largely depending on sea water desalination, said that water was not a major environmental problem. Those who thought water was not a major problem or no problem at all included $64 \%$ in Bahrain, $52 \%$ in Tunisia, 41\% in Qatar, 35\% in Oman and Kuwait and 31\% in UAE." In contrast, in Sudan and Iraq, over $90 \%$ of the population ranked access to freshwater as a major problem, which can be attributed to the poor state of public infrastructures despite both countries being well endowed with freshwater resources (Tolba and Saab 2008).

While almost all countries in the region have sought to expand water distribution and storage systems through dams and canals, significant demand management of water consumption was not taken until severe droughts and falling water supplies in aquifers and reservoirs became critical. This has been the case in Israel, Saudi Arabia, Morocco, Bahrain, and increasingly in Jordan, Algeria, and Yemen. Nonetheless, agricultural products account for a large share of merchandise exports from many MENA countries (De Rosa 1997). ${ }^{3}$ Changes in agricultural production in MENA states due to water shortages induced from climate change and/or changes in water allocations, will severely impact farming constituencies in the absence of effective state and community interventions.

\footnotetext{
${ }^{3}$ In the late 1990s, agriculture as a share of merchandise exports was the following: Cyprus (32\%), Lebanon and Turkey (approximately 25\%), Jordan and Syria (about 20\%), Sudan (95\%), Mauritania (49\%) and Morocco (28\%; De Rosa 1997, p. 8).
} 


\section{Climate change impacts on precipitation}

Projections for future renewable water resources in the MENA are bleak, and climate change coupled with increasing water demands are likely to amplify the water crisis in the MENA. The Intergovernmental Panel on Climate Change (IPCC) report predicts "annual rainfall is likely to decrease in much of Mediterranean Africa and northern Sahara, with the likelihood of a decrease in rainfall increasing as the Mediterranean coast is approached" (IPCC 2007, Chapter 11, p. 866). Several other independent studies have also suggested a major reduction in precipitation, ranging from $10 \%-30 \%$ in the MENA by the next century (Conway and Hulme 1996; Arnell 1999; Sánchez et al. 2004; Milly et al. 2005; Suppan et al. 2008; Alpert et al. 2008; Evans 2008a, b, 2009). In particular, these studies predict that by the end of the twenty-first century, the Mediterranean region might experience a substantial increase and northward extension of arid regime lands, which would affect the coastal regions of MENA and extend to Mediterranean islands, southeastern Europe (particularly Spain), and the Turkish peninsula (Gao and Giorgi 2008; Evans 2008a, b, 2009). During the last 5 years, there has been a significant reduction in the amount of precipitation in the MENA, which is already the most water-stressed region worldwide. UNDP (2007/2008, p. 95) noted that "nine out of fourteen countries in the region already have average per capita water availability below the water scarcity threshold" ${ }^{4}$ Gaza, in particular, is one of the most water stressed places in the world with about 320 cubic meters annually per person (UNDP 2006, p. 135).

The Levant (Syria, Lebanon, Palestine, and Israel) will be one of the regions in the Middle East most affected by changes in precipitation. Most climatic models predict a decrease in precipitation combined with a surface temperature increase in the Eastern Mediterranean (Alpert et al. 2008), which will result in decreased water availability and enhanced water deficit in the Lower Jordan River basin (Israel, West Bank, and Jordan; GLOWA 2009). High resolution climatic models conducted in the Middle East predict an increase in mean annual temperature up to $4.5^{\circ} \mathrm{C}$ that coincides with a $25 \%$ decrease in mean annual precipitation towards the end of the twenty-first century (Suppan et al. 2008). These and other models also predict changes in spatial precipitation distribution in which precipitation in the northern section of the Levant will experience greater reductions than in other parts of the region (Suppan et al. 2008; Steinberger and Gazit-Yaari 1996). Consequently, precipitation is predicted to decrease by $25 \%$ in the Upper Jordan River catchment and aquifer recharge zones in northern Israel, Lebanon, and Syria (Suppan et al. 2008). In Jordan, the average annual water yield (i.e., aquifer replenishment) is expected to decrease by a staggering percentage $(45 \%$ to $60 \%)$ due to combination of a $2^{\circ} \mathrm{C}$ increase in temperature along with $10 \%$ reduction in precipitation (Oroud 2008). Thus, the present water deficit in Jordan is expected to intensify further. According to the 2007-2008 Human Development Report, similar deficits are forecast for Syria, where a $50 \%$ decline in renewable water availability is expected by 2025 , compared to 1997 levels (p. 95).

${ }^{4}$ Less than $1,000 \mathrm{~m}^{3}$ per capita is considered water stressed (Falkenmark 1986). 
Fig. 1 Changes of water levels in the Sea of Galilee, Israel during the last century. In 1934, the outlet level was reduced to accommodate the downstream Naaharim electrical project. In 1964, the National Water Carrier started operations. The droughts of late 1990s, early 2000s and late 2010 s are associated with the lowest water levels in the lake history. Data from Ami Nishri (Israel Oceanographic and Limnological Research)

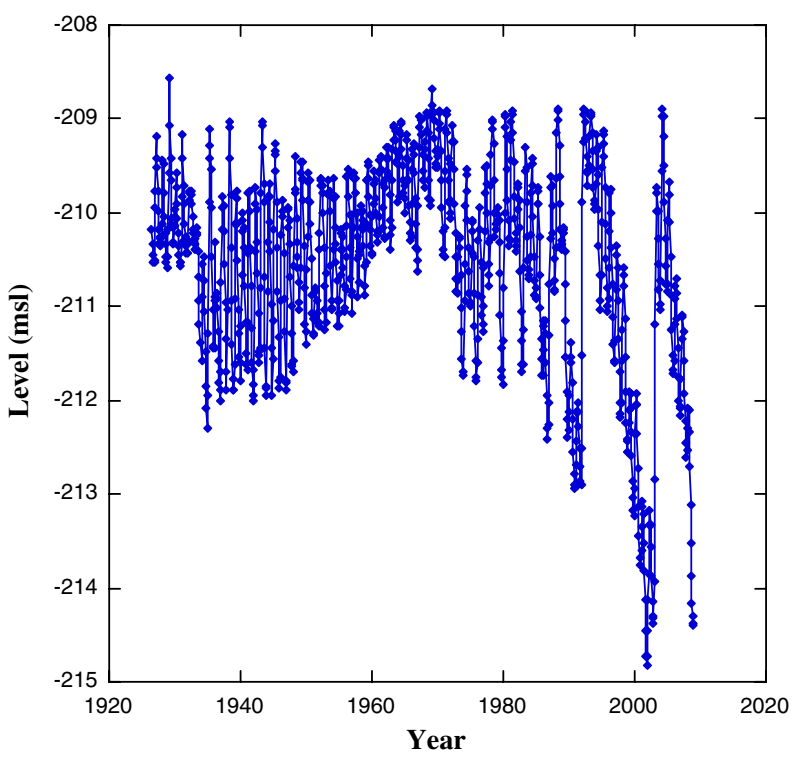

Declining precipitation has had unprecedented effects in Israel-a country renowned worldwide for being at the forefront in water efficiency. For instance, the National Water Company, Mekorot, entirely stopped its pumping from the Sea of Galilee in January 2009 after its level had dropped to a point considered to be near the "bottom black line." 5 Figure 1 illustrates the fluctuations of water levels in the lake during the last 90 years and the impact of the consecutive drought conditions in the region on the lake levels, particularly during the last decade. Although pumping through Israel's National Water Carrier controls the level of the Sea of Galilee, the amount of pumping remained steady during years of average precipitation, and in fact, was significantly reduced during drought years. The sharp decline of the water levels is, therefore, a direct consequence of decreasing inflows to the lake during the last 30 years. This phenomenon is consistent with actual observations of surface warming in the MENA region (Zhang et al. 2005) and the climatic models (Conway and Hulme 1996; Arnell 1999; Suppan et al. 2008; Alpert et al. 2008; Sánchez et al. 2004; Milly et al. 2005; Gao and Giorgi 2008; Evans 2008a, b, 2009).

Other watersheds in the region show similar trends with regards to declining amounts of precipitation. For Morocco, precipitation over the Atlas Mountains will determine the flow in major rivers and replenishment of several important aquifers of the Souss-Messa, Draa, Ziz, and Tadla basins (Bouchaou et al. 2008). Recent climatic models for eastern Mediterranean and Turkey predict a significant reduction in precipitation (Gao and Giorgi 2008) that would require additional water withdraws

\footnotetext{
${ }^{5}$ Before the 2006-2009 drought, the Water Commission only had a "red" line that could not be reached. But as the situation deteriorated, the Commission (now Authority) created new "black" lines that indicate the point where irreversible damage would occur if pumping continues (Waldoks 2009).
} 
from the Tigris and Euphrates Rivers to meet agricultural demand in southeastern Turkey. The increase in upstream withdrawals by Turkey and reduction of the Tigris and Euphrates flows to the downstream Syria and Iraq could have devastating effects on the water availability in these counties.

For Egypt and Sudan, changes in precipitation patterns over the Ethiopian Highlands are the key for future flow of the Nile River, yet climatic models are inconclusive for the projected trend (Conway 2005). Higher temperatures, however, produce higher rates of evaporation, particularly in Lake Nasser, the large man-made reservoir behind the Aswan High Dam. Likewise, an increase of evaporation of the White Nile River along the sluggish flow in the Sudd area of southern Sudan would reduce the annual river discharge. Increased rates of evaporation-and water lossin the reservoir will thus likely offset possible increased precipitation in the central and eastern African highlands.

\section{Population growth, water scarcity, and climate change}

Water scarcity and an uneven distribution of freshwater resources are exacerbated by expected rapid demographic growth. Vörösmarty et al. (2000) has compared possible global precipitation changes induced by climate change and water demands controlled by population growth. Their predictions indicate that the impact of increasing water demands derived from population growth is larger than the effects of climate change; the latter includes both an increase of aridity in some areas and an increase of rainfall in others. Conway (2005), in a review of ten studies undertaken on Nile flow and climate models since 1981, similarly concluded that the climaterelated impacts of variable Nile flow will be relatively minor in comparison with other human-induced changes, namely, population growth, land use choices, and development strategies.

The rapid increase in population in the MENA region is illustrated in Fig. 2. Overall, total population is expected to grow from 309 million in 2000 to about 651 million in 2030 (data from Shahin 1996). Water availability varies by several orders of magnitudes for the different countries in the MENA region and so fresh water availability per capita ranges from highly water stressed countries like Jordan (200 $\mathrm{m}^{3} /$ year/capita) to less water-stressed counties like Iraq (4,340 $\mathrm{m}^{3} /$ year/capita; Fig. 3).

Countries with surplus water supply are based on surface water flows (Iraq, Syria, Lebanon, Egypt, Sudan), whereas groundwater-based countries have significantly higher water stress at present. For instance, the most populous Arab state, Egypt, is comparably well endowed with renewable water resources, since it receives $96 \%$ of its water resources from the Nile River. In contrast, the Arabian Peninsula and North Africa (with the exception of Morocco) have more limited flows of renewable water, and typically draw on 'fossil' (nonrenewable) aquifers to meet current demands. Given its relatively large and growing population (Fig. 2), however, in per capita terms aggregate water supply in Egypt will become increasingly constrained (estimated $590 \mathrm{~m}^{3} /$ year/capita in 2025, Fig. 4) compared with Iraq (2,200 $\mathrm{m}^{3} /$ year/capita).

Assuming no change in water availability, expected population growth for 2025 will dramatically increase the water stress in the MENA region, as water availability per capita is expected to decrease in the range of $30 \%$ to $70 \%$ (an average of $42 \%$ ). 
Fig. 2 Population growth in several countries in the MENA region. Data from Shahin (1996)

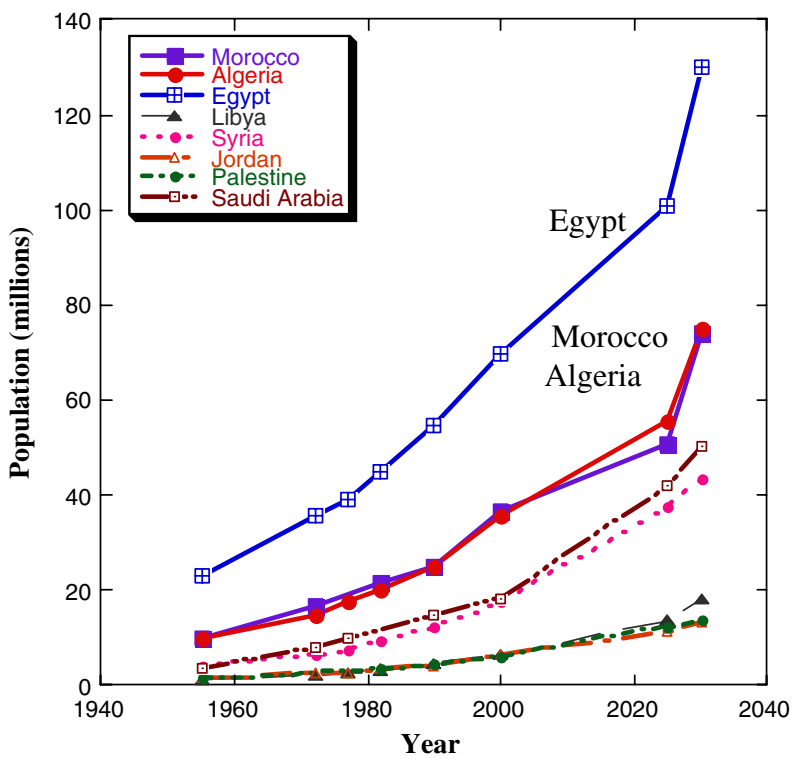

The expected increase in water stress (defined here as less than $500 \mathrm{~m}^{3} /$ year/capita) will affect most countries in the MENA region (Fig. 4), but in groundwater-based countries, which already suffer from water stress, population growth will exacerbate the already existing water crisis.

In surface water-based countries, the absolute water availability per capita will exceed the threshold of $500 \mathrm{~m}^{3} / \mathrm{year} / \mathrm{capita}$ that defines water stress (Morocco, Egypt,

Fig. 3 Water availability per capita (cubic meter/year/person) in several countries in the MENA region. Values were calculated from data reported in Shahin (1996). Note that the values in this figure are different from those reported in Table 1, as the latter are per capita withdrawal and not per capita availability water availability per capita (2000)

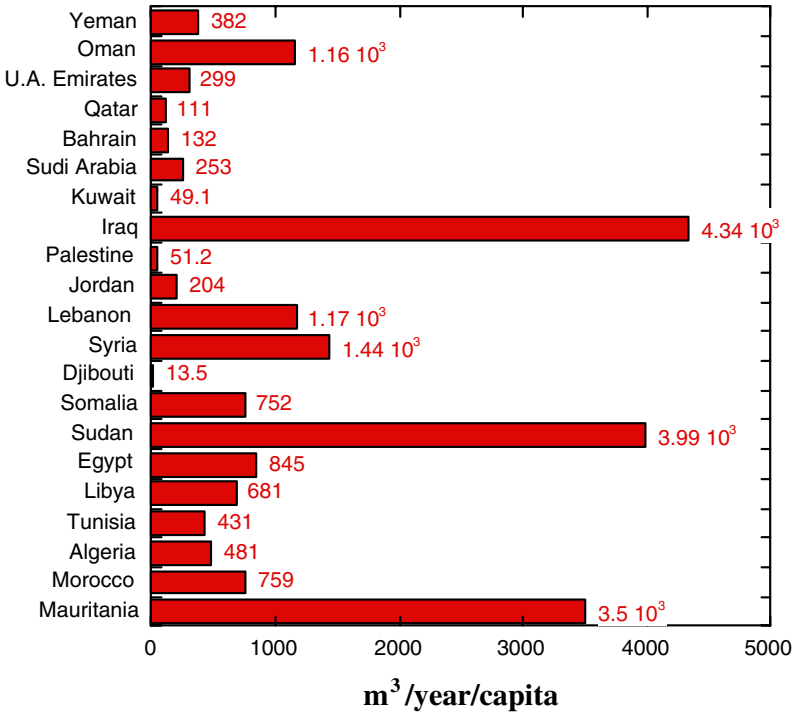


Fig. 4 Water availability per capita (cubic meter/year/person) predicted for 2025 in several countries in the MENA region. Figures were calculated based on the assumption that water availability (Fig. 3) will not be changed but population growth will increase water demands. Values were calculated from data reported in Shahin (1996) water availability per capita (2025)

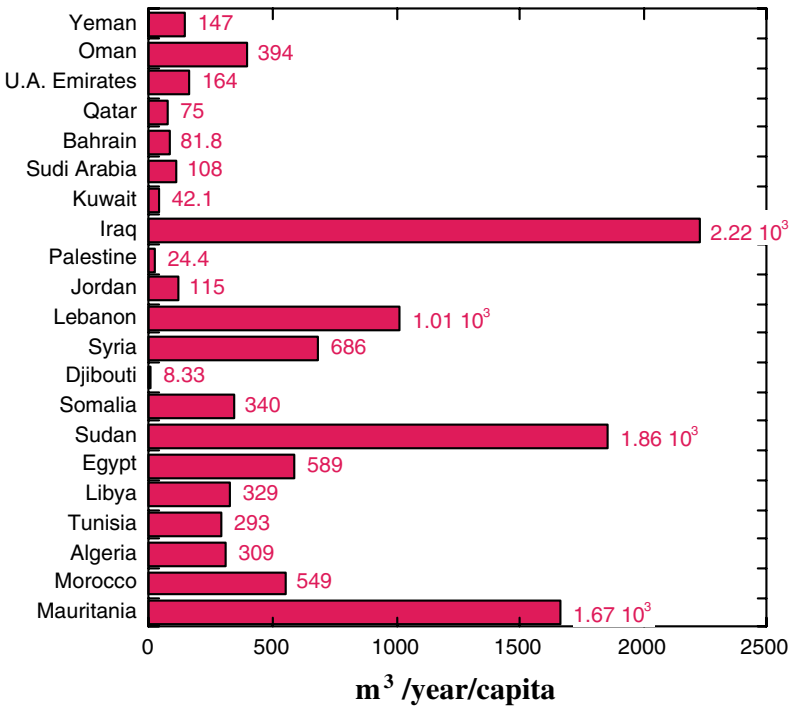

Sudan, Syria, Lebanon, and Iraq) in 2025. ${ }^{6}$ This is based on the assumption that the river discharge in these countries will not vary significantly from 2000 figures. However, if we take into account the climate change factor, surface water-based countries may experience a dramatic reduction in surface flow, if global warming affects precipitation in intake areas of their rivers. Consequently, while population growth is expected to affect all countries in MENA region, climate change could have a greater affect on countries in which water supply is based on surface water.

\section{Impacts on sea level rise and coastal water resources}

In addition to a reduction in precipitation, the rising of the Mediterranean Sea induced by climate change is expected to affect coastal communities. The coastal aquifers of the Levant and North Africa already suffer from seawater intrusion that causes salinization of thousands of wells (Vengosh and Rosenthal 1994; Vengosh et al. 1994, 1999, 2005; Weinthal et al. 2005). Coastal plains in MENA are the most fertile lands and often extensively cultivated. For example, the Souss-Messa basin in southwestern Morocco produces a large fraction of Morocco's agricultural exports. Over-exploitation of this coastal aquifer has caused massive intrusion of seawater coupled with man-made contamination (Bouchaou et al. 2008). Likewise,

\footnotetext{
${ }^{6}$ Likewise, Bou-Zeid and El Fadel (2002, pp. 345-346) find that owing to high rates of population growth, it is expected that by 2025 the average annual renewable water resources for the Middle East will drop to $667 \mathrm{~m}^{3}$ per capita in contrast to the world average of $4,780 \mathrm{~m}^{3}$ per capita.
} 
the salinity of the Israeli coastal aquifer has increased during the last 30 years due to combination of over-pumping, seawater intrusion, nitrate pollution, and formation of saline plumes (Vengosh et al. 1999, 2005). Further intrusion due to the rise of sea level combined with less fresh water recharge into these coastal aquifers will enhance inland encroachment of seawater (Bou-Zeid and El Fadel 2002) and intensify other salinization phenomena (Vengosh 2003; Weinthal et al. 2005). In short, rapid degradation of water quality in replenished aquifers in the coastal MENA region will intensify with reductions in fresh water recharge.

Sea-level rise (SLR) presents a significant risk to many countries in the region. A World Bank study (Das Gupta et al. 2007) estimated adverse impacts of sea level rise on the Arab countries. In the region's most populous Arab state, Egypt, rising sea levels will require significant investments in protective structures in order to avoid widespread population displacement. In the absence of such investment, under the scenario of a one- meter SLR, Das Gupta et al. (2007, p. 18) found that $10 \%$ of Egypt's population (an estimated 6 million people) would be affected and $12 \%-15 \%$ of the agricultural land of the Nile Delta could be lost. Even if direct inundation is prevented, rising sea levels will change the freshwater-saline interface, rendering some of the fertile coastal agricultural areas increasingly difficult to cultivate. Egypt's Mediterranean coastal cities are particularly vulnerable, as climate change impacts will interact with ongoing coastal erosion (Egyptian Environmental Affairs Agency 1999; Kreimer et al. 2003).

In addition, a significant proportion of the population depends upon an array of economic activities situated at or below sea-level in coastal areas of the Nile Delta. These extend beyond resource-dependent activities such as agriculture and fisheries, but also include much of the tourism and industrial infrastructure, natural and cultural heritage sites, and fragile ecosystems, such as the large brackish lakes of Egypt's northern coastline. Thus, in terms of population impacted, Egypt is the most vulnerable of all the Middle Eastern states to any increase in sea-level, followed closely by the United Arab Emirates and Qatar (El Raey 2008; Das Gupta et al. 2007, p. 20).

\section{Water scarcity, climate, and agriculture}

Because the MENA is predominantly arid and hyperarid, significant agricultural production relies on public or private irrigation using surface water, groundwater, or some combination. The water and agricultural sectors are, therefore, tightly coupled. In most of the MENA countries, the agricultural sector is the largest consumer of water. On average, it accounts for approximately $80 \%$ of water budgets (see Table 1), but reaches $90 \%$ and above for six countries in the region. This means that reallocations of water under conditions of scarcity will most likely be at the expense of the agricultural sector, as has already been the case in Yemen, Jordan, Israel, and Libya. The agricultural sector also accounts for a significant share of employment in some countries, accounting for 28\% of employment in Egypt, 44\% in Morocco, and $50 \%$ in Yemen (World Bank 2007, p. 61).

Liberalization of agricultural sectors, pursued by governments across the region during the 1980s and 1990s, has posed new challenges for managing irrigation demand. Governments have withdrawn from setting crop prices and quotas for most 
Table 1 Freshwater withdrawal by sector

Data Compiled from The World's Water, 2004-2005

\begin{tabular}{lrrrl}
\hline Country & Year & $\begin{array}{l}\text { Domestic } \\
\text { use }(\%)\end{array}$ & $\begin{array}{l}\text { Industrial } \\
\text { use }(\%)\end{array}$ & $\begin{array}{l}\text { Agricultural } \\
\text { use }(\%)\end{array}$ \\
\hline Algeria & 2000 & 22 & 13 & 65 \\
Bahrain & 2000 & 40 & 4 & 57 \\
Djibouti & 2000 & 11 & 0 & 89 \\
Egypt & 2000 & 8 & 14 & 78 \\
Iran & 2000 & 7 & 2 & 91 \\
Iraq & 2000 & 3 & 5 & 92 \\
Israel & 2000 & 31 & 7 & 63 \\
Jordan & 2000 & 21 & 4 & 75 \\
Kuwait & 2000 & 45 & 3 & 52 \\
Lebanon & 2000 & 33 & 1 & 67 \\
Libya & 2000 & 8 & 3 & 89 \\
Morocco & 2000 & 8 & 2 & 90 \\
Oman & 2000 & 7 & 2 & 91 \\
Qatar & 2000 & 25 & 3 & 72 \\
Saudi Arabia & 2000 & 10 & 1 & 89 \\
Syria & 2000 & 3 & 2 & 95 \\
Tunisia & 2000 & 16 & 2 & 82 \\
UAE & 2000 & 23 & 9 & 68 \\
Yemen & 2000 & 4 & 1 & 95 \\
\hline
\end{tabular}

crops, and gradually withdrawn subsidies on some foodstuffs. Agricultural demand has risen in response to increasing food prices and the spread of new pumping technologies. With mobile diesel pumps, farmers in the region can directly access groundwater sources, contributing to overextraction of aquifers (Achthoven et al. 2004).

National water institutions are thus unable to prevent private actors from appropriating water at will. For instance, in Jordan of approximately 2,000 water wells that are overexploited, at least half of them were constructed illegally. ${ }^{7}$ In Gaza, the Palestinian Water Authority was unable to prevent rampant digging of wells. One water expert postulated that in 1994 there were only about 2,000 wells in Gaza, but by 2000 at least another 1,000 wells were dug. ${ }^{8}$ Similarly, in Yemen, government officials have been unable to prevent the illegal drilling of wells in the Sanaa basin to support the cultivation of qat, a plant widely consumed for its narcotic effects (Kasinof 2009). In Libya and much of North Africa, declining aquifer levels in coastal areas are also directly attributable to uncontrolled and illegal pumping for agriculture. ${ }^{9}$ In all these areas, overpumping enhances seawater intrusion and the flow of other saline sources, eventually limiting possibilities for further cultivation.

Reliance on individual pumping, whether licit or illicit, also reflects significant problems in state provision of public goods - that is, the reliable provision of good quality irrigation water to agricultural communities. As in many other state-

\footnotetext{
${ }^{7}$ See http://www.jordan-business.net/magazine/index.php?option=com_content\&task=view\&id= $266 \&$ Itemid $=40$.

${ }^{8}$ Personal communication to EW, former member of the Israeli Civil Administration in Gaza (January 2000).

${ }^{9}$ Personal communication to JS, Libyan water engineer (May 2008).
} 
controlled and owned resource systems in the MENA, irrigation and drainage systems face inadequate maintenance, significant losses, and increasing demand from a variety of users. Aggregate water statistics obscure the fact that many users, particularly at the tail ends of irrigation canals, face periodic and unpredictable shortages due to poorly maintained infrastructure and increased withdrawals by upstream users.

Within this constrained context, climate-related impacts on agriculture are expected to be significant (Cline 2007, chapter 5). Many crops are already cultivated at the extremes of their tolerances to heat and salt; increasing temperature is expected to lower yield and shift cultivation patterns (Eid et al. 2007; GLOWA 2009). Egyptian agronomists have estimated climate impacts on agriculture, combining standard global circulation climate models with multi-year, multi-crop models to simulate outcomes under a variety of cropping systems and management interventions. Most crops under these simulations showed increased water requirements due to higher temperatures and lower yields. This was particularly true for grains, including maize, wheat, sorghum, barley, and rice. All showed significant declines in yields, ranging from $9 \%$ to $19 \%$ for a two-degree average temperature rise, along with increased water consumption of $2 \%-16 \%$ (Eid et al. 2007).

An additional aspect of the fragility of the agriculture sector is the expected degradation of the quality of irrigation water, associated directly and indirectly with climate change. Long-term salinization has been observed in many of the aquifer systems in MENA, including Morocco (Bouchaou et al. 2008), Israel (Vengosh et al. 1994, 1999; Gvirtzman et al. 1997), Gaza Strip (Vengosh et al. 2005; Weinthal et al. 2005), Jordan Valley (Marie and Vengosh 2001; Farber et al. 2004), and Mafraq (Rimawi and Al-Ansari 1997) and Azraq (Al-Kharabsheh 2000; Bajjali and Al-Hadidi 2005) basins in Jordan. An overall decrease in aquifer replenishment would amplify these salinization phenomena. Increasingly saline irrigation water is expected to severely reduce land suitability for vegetable and fruit tree cultivation in the Lower Jordan Basin of Israel, West Bank, and Jordan (GLOWA 2009).

\section{The political economy of adaptation}

A recent study by the World Bank (2007) found that formal water policies and institutions in the MENA scored significantly better than a comparable set of institutions in 27 low and middle-income countries, in terms of formal regulatory frameworks and organizational capacities. As the World Bank (2007) also noted, however, governmental water capacities have not yet translated into commensurate gains in water efficiency, conservation, or user participation. Yet managing water demand, improving the efficiency of water use, and promoting conservation will be key ingredients in responding to climate-induced impacts on the water sector.

Demand management and participatory water strategies typically rely on greater interaction with communities and local governments than policies implemented through centralized water provision and planning. Much of the environment and development literature has emphasized the importance of social capital, state-society synergy, public-private partnerships, community-based resource management, and co-production of public goods in fostering effective policy interventions (Evans 1996; Lemos and Agrawal 2006; Ostrom 1992). These kinds of embedded linkages 
or "nested institutions" are also increasingly invoked in explaining resilience and adaptive capacity of governance systems (Ostrom 1990; Dietz et al. 2003).

Water policy innovations, however, encounter significant obstacles in the MENA, given the nature of political regimes and the political-economic interests vested within them. First, water management remains centralized in governmental ministries vested for both bureaucratic and ideological reasons in supply-side approaches to water management. At the same time, existing centralized systems of water allocation, through irrigation networks and urban water supplies, create relatively privileged constituencies, in both urban and rural areas (Richards 2002). Lastly, the authoritarian and quasi-democratic regimes of the Middle East, as the Arab Human Development reports have consistently noted, have undermined reserves of 'social capital.' Widespread mistrust of governmental agencies and intentions, and overextended, underfunded state institutions, mean social actors often develop alternative means to access resources and seek to avoid entanglement in government initiatives. These features of the political landscape make significant water policy reforms difficult. In light of these political constraints, we review the predominant policy responses.

\subsection{Searching for supply}

Most MENA countries still emphasize supplementing water supplies more than managing water demand. Given population growth rates, some additional supply capacity is necessary. More tellingly, however, governmental ministries charged with water management view water management primarily as a civil engineering problem (Richards 2002). ${ }^{10}$ Thus, despite changing precipitation patterns and increasingly frequent droughts, water policy is still limited largely to increasing supply through costly measures such as desalination, reuse of treated wastewater, and water storage infrastructure.

Countries such as Egypt, Morocco, Lebanon, and increasingly Saudi Arabia have invested heavily in water storage schemes through the construction of dams, reservoirs, weirs, and other catchment technologies. These have ranged from the very large-scale, as in the Aswan High Dam, to very small-scale dams designed to catch run-offs during flood events in small wadis (creeks). Small-scale water catchment schemes are particularly useful in areas of erratic rainfall and sparse or nomadic populations, where centralized water supply schemes are impractical. Water storage schemes can also be used to recharge aquifers; this policy measure has begun to be applied in Iran and Saudi Arabia (CEDARE 2005).

\subsection{Desalination}

Most countries that can afford to in MENA have added desalination capacity in order to meet existing demand that far exceeds renewable water resources, making

\footnotetext{
${ }^{10}$ Even within the context of shared water basins, Israeli officials have frequently emphasized technological solutions to augment supply (Weinthal and Marei 2002).
} 
the region the world leader in desalination technology investments (World Bank 2007, p. 38). Saudi Arabia is the world's leader in desalination capacity, accounting for approximately $26 \%$ of global production (Miller 2003, p. 30). While the Gulf states (in particular, Saudi Arabia) possess the highest percentage of desalination installations, countries outside of the Gulf (e.g., Algeria, Egypt, Israel, Jordan, Libya, Tunisia) have increasingly been investing in desalination to augment supply. ${ }^{11}$ For example, while desalination in Israel in 2009 (about $140 \times 10^{6} \mathrm{~m}^{3}$ ) accounts for $20 \%$ of domestic water consumption, the government has accelerated the building of new desalination plants, aiming to supply about $600 \times 10^{6} \mathrm{~m}^{3}$, which is $80 \%$ of drinking water consumption by 2013 (Rinat, March 26, 2009 in Ha'aretz).

\section{3 'Fossil' groundwater use}

Many countries have planned new schemes to draw on large fossil water aquifers. Jordan, like Egypt, Libya, and the Gulf states, has begun exploring the extraction of fossil water supplies. This is generally cheaper in the short-term than desalination capacity. Jordan has initiated a new water project to pump and transport fossil water from the Disi aquifer in the south to the capital Amman (Jaber and Mohsen 2001; Mohsen 2007). This aquifer, known also as Saq aquifer, has been utilized extensively in Saudi Arabia (Lloyd and Pim 1990). The recent discovery of high radioactivity in this aquifer (Vengosh et al. 2009) would require, however, further investment for remediation given the health risks associated with long-term consumption of high radium water (ibid). Egypt and Libya are jointly drawing on the Nubian Sandstone Aquifer for irrigation and human consumption. Egypt uses this groundwater to accelerate development in its Western oases, whereas Libya taps the aquifer through the Great Man-Made River (GMR) to bring water to its populated coastal areas, where most of the country's agriculture is also located. Other countries such as Morocco have turned to large-scale interbasin transfers to redistribute water resources (World Bank 2007, p. 36).

\subsection{Reuse of treated wastewater}

Another supply-side strategy has been to expand the reuse of treated domestic wastewater as a means to augment water supplies: treated wastewater provides $12 \%$ of Jordan's irrigation water and in Tunisia, 30\% of treated wastewater is reused in agriculture (World Bank 2007). In Israel, treated wastewater is an important component of the agricultural sector (about $400 \times 10^{6} \mathrm{~m}^{3}$ per year in 2008). The dramatic decrease in water allocation to the agriculture sector during the drought of 2007-2008 was made possible due to the availability of treated wastewater, which was $36 \%$ of the total water consumed by the agricultural sector in Israel (data from Israel Water Authority, http://www.water.gov.il).

\footnotetext{
$\overline{{ }^{11} \text { According to one estimate, } 35}$ desalination plants have been built thus far in Saudi Arabia at a cost of $\$ 10$ billion (Abderrahman 2001).
} 
In spite of the progress in sewage treatment technology, however, reuse of wastewater is not always possible and is limited by the content of salts, boron, pharmaceuticals, and other substances. The salinity and boron contents of domestic wastewater are typically higher than that of most of fresh water aquifers, as typical sewage treatment does not remove inorganic constituents such as boron and chloride. Consequently, inorganic salts are enriched in sewage effluents (Vengosh et al. 1994; Inbar 2007), which limits its application for salt-intolerant crops.

Another limiting factor for the reuse of sewage effluents for agriculture is the source of drinking water that eventually is turned into wastewater. Seawater desalination by reverse osmosis (RO) under normal operational conditions would remove only a small fraction of boron, resulting in high levels in drinking water and consequently in treated wastewater. In order to overcome this problem, the recent RO desalination in Ashqelon, Israel was designed specifically to remove boron below 0.3 ppm (Kronenberg 2004; Sauvet-Goichon 2007; Gorenflo et al. 2007) to prevent the recycling of boron-rich wastewater into the agriculture sector. Likewise, seawater RO desalination requires adequate post-treatment systems in order to provide sufficient calcium and magnesium contents in desalted water to be used effectively as recycled wastewater (Lahav and Birnhack 2007). Future utilization of wastewater for agriculture in MENA would therefore have to consider these limiting factors in designing their water management system if RO desalination plants are pursued.

\subsection{Horizontal expansion of irrigated land}

One striking feature of many MENA political economies is the long-standing commitment to expanding irrigated agriculture, often by "overbuilding" irrigation infrastructures beyond physical capacities of river basins and aquifers (Molle and Berkhoff 2006). Even as groundwater reserves are drawn down in many countries and salinization threatens existing irrigated areas, horizontal expansion of agricultural land remains a declared priority for many regimes. The expansion of arable land into desert frontiers has been central to state building projects and nationalist ideologies in countries as diverse as Egypt, Israel, Libya, Turkey, and Saudi Arabia (for Israel, see De-Shalit 1995; for Egypt, see Sowers forthcoming b).

In Libya, the GMR takes fossil water hundreds of kilometers from the arid interior and distributes water to the populated coastal areas through a network of pipes (Mashru` al-nahr al-sina i al-'azim 1989; Tantawi 1990). Initial plans for the GMR included large-scale land reclamation but increasingly urban and industrial needs trumped those of agriculture. Initiated in the 1980s with technical assistance from Halliburton, the GMR was plagued by cost-overruns and technical problems. It is now substantially complete, and has allowed Libya to rely less on desalination than other sparsely populated oil-exporting countries (Ford 2003).

In Turkey, the government prioritized the construction of 22 dams and 19 hydroelectric power plants in the GAP or Southeastern Anatolia Project, part of state plans to incorporate and pacify the Kurdish population in the southeast region. The project began in 1977 with the goal of expanding irrigated agriculture by an additional 1.7 million hectares. Under international criticism, the Turkish state has gradually added other investments such as schools and healthcare clinics. Yet participatory assessments and other forms of consultation with local populations have been absent 
in light of ongoing civil conflict and state violence in the largely Kurdish region (Ronayne 2005). While several dams, such as the Illisu dam, have been delayed due to international and local protest, most of the planned infrastructure has been completed (e.g. Warner 2008).

Egypt has also embarked on large-scale land reclamation projects. Designed to increase Egypt's habitable area from $4 \%$ to $25 \%$, these projects included the Al-Salam Canal (Peace Canal) to mix Nile water with drainage water to irrigate northern Sinai, and the New Valley project, to divert Nile water to parts of the Toshka depression in south-western Egypt. Egypt built the world's largest pumping station (the "Mubarak" pumping station) for the Toshka project and offered longterm concessions to attract private investors, but found few willing to invest far from centers of population, transport, and distribution (Salem 2005). At present the pumping station uses only a fraction of its capacity, due to lack of irrigation demand, but the government continues to market the project to agribusiness investors from Egypt and the Gulf (Sowers forthcoming b).

Hydrologists and social scientists alike have generally considered Egypt's investment in these 'megaprojects' excessive (Allan 2001; Ayeb 2002; Elarabawy and Tosswell 1998). The era of large state-sponsored horizontal irrigation projects, however, may be rapidly coming to an end. As the Egyptian Ministry of Irrigation's Integrated Water Resources Management Plan observes "it should be realized that by implementing all these measures, in particular all of the planned horizontal expansion projects, the water resources systems has reached its limits of what it can support" (Ministry of Water Resources and Irrigation 2005).

\subsection{New paradigms of water management}

Given the increasing costs associated with producing additional supplies of water, and diminishing quality of existing sources, regional water experts in MENA and international development institutions have begun advocating IWRM (Fischhendler 2008; Mohorjy and Grigg 1995; Kandil 2003; Elarabawy et al. 2000). IWRM emphasizes inter-governmental coordination and enhanced participation from diverse communities of water users. MENA experts have convened new forums and networks to disseminate norms of IWRM and water demand management (Sowers forthcoming a). These include the Arab Water Council, founded in 2004 as a non-government professional organization, and the Global Water PartnershipMediterranean, founded in 2002 as an ongoing partnership for activities associated with the Mediterranean Environmental Technical Assistance Program (METAP), a multi-donor funded project. A range of other non-governmental research centers also serve as hubs for disseminating new norms of water management, such as CIDA (The Canadian International Development Research Center) and ICARDA (the International Center for Agricultural Research in Dry Areas) located in Aleppo. These efforts are supported by a number of international development institutions.

In general, international organizations strive to construct isomorphic environmental structures across countries, in order to promote convergence in environmental practices such that all countries possess similar institutional templates for understanding environmental change (Weinthal 2002). For the MENA water sector, institutions supporting policy reforms in the water sector include the World Bank and the Global Environmental Facility, the specialized agencies of the United Nations, 
particularly the United Nations Environment Program (UNEP), the United Nations Development Program (UNDP), the Economic and Social Commission for Western Asia (ESCWA) of UNESCO, and the Food and Agriculture Organization (FAO). ${ }^{12}$

International donors have increasingly embarked on partnerships with MENA water experts based in government ministries. Increasingly some of these initiatives involve multiple donors and multi-year funding. For example, the Water Demand Initiative for the Middle East and North Africa (WaDimena) is a 4year project explicitly designed to target demand management by working with local communities and supporting domestic scientific research in the Arab countries (http://www.idrc.ca/wadimena/). Although Israel, Turkey, and Iran are absent from some of these forums, they too have adopted similar institutional structures and reporting requirements, suggesting that dissemination of new norms for water management follow multiple avenues of diffusion.

This diffusion of 'best practices' in water management, however, has not yet moved significantly beyond the domain of water experts at the highest echelons of water bureaucracies. These experts are often limited in their ability to foster reform either in their own institutions or across other government ministries and sectors. For instance, while leading officials at Egypt's water ministry supported efforts by international donors to establish water users associations to manage water more efficiently since the early 1990s, the government has not yet legally recognized or devolved decision-making authority over local irrigation to these associations (Sowers forthcoming a).

Environmental agencies that might promote alternative water management approaches are relatively underdeveloped and kept distinct from water resources planning in much of the MENA. Most states in the region have created environmental agencies or appended environmental functions to existing ministries. However, many of these institutions do not enjoy the same statutory and regulatory powers as other central government agencies such as ministries of water and agriculture. In Israel, for example, water allocation and distribution is controlled by the water authority, which is part of Ministry of Infrastructure, whereas the Ministry of Environment has a minimal input, even in topics related to water quality. The Ministry of Environment holds a similarly secondary status to the ministries of irrigation, housing, public works and planning in the Arab countries (Assaf 2008).

Many developing countries, including those in MENA, furthermore do not have adequate scientific capacity to conduct local research into climate-water dynamics. Only a few, such as Egypt and Israel, have local scientists with the expertise and resources to conduct research, while others, such as the various small Gulf states, can afford to import consultants and scientists. Several initiatives, such as USAIDfunded projects, Germany-funded GLOWA project, and the Mediterranean Action Plan, have initiated joint research programs that include scientists from the region

\footnotetext{
${ }^{12}$ Also see Euro-Med (2008) Integrating the climate change dimension into water resources management in the Mediterranean presented by Morocco, Spain and Greece with the contribution of the MED EUWI Secretariat, in view of the Euro-Mediterranean Ministerial Conference on water, 29 October.
} 
and experts from overseas. ${ }^{13}$ Overall, the scientific infrastructure necessary to plan specific, localized adaptive measures is limited.

Water experts and climate researchers also encounter a number of political constraints. Political leaderships remain unconvinced about the need to adaptively plan for climate-related impacts on water given immediate priorities of providing and expanding water provision. For example, in Egypt, climate scientists have recommended establishing high level committees representing government, research, and civil society partners; this has yet to materialize. An inter-ministerial committee on climate change was established but has yet to meet more than once. ${ }^{14}$

The security concerns that dominate many states in the MENA take their toll on climate and water research activities and efforts to enhance their adaptive capacity. Conflict between Israel and its Arab neighbors has limited cooperation over water and environmental issues (Brown and Crawford 2009; Weinthal et al. 2005). In Egypt, several climate researchers have found that international collaborations involving the use of satellite imagery to analyze climate impacts were rejected by the military on national security grounds. ${ }^{15}$ These limitations compound the long-standing problems of scientific emigration (the 'brain drain'), inadequate compensation, and limited investment in scientific research that characterize many developing countries.

\section{Adaptation in the agricultural sector}

\subsection{Expanding reliance on trade}

The most obvious adaptive measure to meet MENA's water needs is to expand reliance on "virtual" water through imports (Allan 1997). However, this strategy relies on domestic economies generating sufficient foreign exchange to cover the costs of imports. Food prices, particularly of cereals, have been kept artificially low through subsidies by the United States and the European Union to grain producers. In addition, the international trade in food, like all commodities, does not yet factor in the environmental costs of carbon from transport, a situation that may change in coming years as awareness of climate change deepens. Rapidly rising food prices in 2008 rekindled concerns about food security throughout the MENA region. ${ }^{16}$

\subsection{Intensification of existing cultivated areas}

Several MENA countries have adopted pricing policies and extension services to increase the cropping intensity of existing cultivated land. By adopting early maturing varieties with higher yields, total yields and cropping intensities have steadily increased in some irrigated areas. In Egypt, total cropped area rose from 4.7 million

\footnotetext{
${ }^{13}$ See http://www.planbleu.org/publications/changement_clim_energie_med_EN.pdf

${ }^{14}$ JS interview with climate scientist, Cairo, (December 2008).

${ }^{15}$ Ibid.

${ }^{16}$ For a discussion of the link between international food prices and incidence of protest and riots, see Cullen et al. 2009.
} 
hectares in 1982 to 6.5 million hectares in 2003, through pricing incentives and extension programs promoting high yield, early maturing varieties of wheat, rice, and maize (Food and Agriculture Organization 2005). With cropping intensities averaging $180 \%$, Egypt has also begun developing heat-tolerant and salt-tolerant crop varieties to cope with changing temperatures and increased salinization (ibid).

\subsection{Accessing arable land in other countries}

Wealthier MENA states have tried to secure rights to arable land and crops in other countries. According to the Arab Organization for Agricultural Development, the price of food imports for the Gulf states increased from $\$ 16$ billion to $\$ 20$ billion between 2006 and 2007 (Montero 2008). Saudi Arabia reportedly considered creating a new holding company in 2008 to purchase overseas farms, including rice farms in Thailand and Indonesia (Economist 2008). Kuwait, likewise, offered Cambodia \$546 million in development loans to finance a dam and build a road, in return for perhaps a long-term lease of 50,000 ha of rice-producing land or guaranteed purchase of the rice crop (Economist 2009b). Many of these deals will most likely be carried out by public-private investment groups and holding companies. For example, the Economist reported that an Abu-Dhabi-based firm, Al Qudra, had acquired large tracts of farmland in Morocco an Algeria, and was seeking acquisitions in Syria, Vietnam, Thailand, Sudan, India, and Pakistan (Economist 2009a).

Such arrangements, however, have typically run into domestic opposition and political instability. Egypt and the Gulf states have intermittently and over decades explored water supply and agricultural ventures in Sudan, the most famous being the Jonglei Canal project. Most of these efforts have been hindered by civil war and ethnic cleansing that have created periodic famines amid chronic hunger. Egypt recently sought access to 840,000 acres of land in Uganda, producing public outrage and resulting in the Ugandan government retracting its commitment (Montero 2008). In Cambodia, rice farmers, NGOs, and opposition parliamentarians have criticized the potential land leases to Kuwait, citing ongoing conflict over displacement of small farmers (Economist 2009b). It is, thus, unlikely that large-scale land transfers or longterm leases will be politically viable.

\subsection{Increasing investment in irrigation and drainage systems}

Tackling domestic water usage in the agricultural sector thus remains an imperative. Losses from poorly maintained and damaged infrastructure are the single greatest source of water savings. This is the case particularly where conflict has rendered public irrigation infrastructures wholly inadequate, as in the Gaza Strip, Algeria, and Iraq (e.g. UNEP 2003). In much of the rest of MENA, irrigation and drainage networks suffer from chronic shortages of investment, which means extensive water losses from the distribution system. These losses may well amount to more water than 'lost' through excess application to crops. One of the most important adaptive measures for MENA is thus to invest in improvements to irrigation systems, but it is costly to do so. Countries such as Egypt rely on a combination of donor and governmental funding to upgrade irrigation and drainage networks, but these efforts have not kept pace with infrastructural needs. 


\subsection{Reallocating water out of agriculture}

Water usage in the agricultural sector has been reduced quite rapidly when water stress threatens the domestic water supply. Agricultural users, often portrayed as powerful interest groups, can quickly find themselves residual users (Molle and Berkhoff 2006). As water crises deepen, urban water supplies typically take priority over agricultural uses, either explicitly through administrative decree or through 'stealth' measures (ibid). In the Middle East, this process has typically taken place under conditions of severe drought or rapid groundwater depletion, to the extent that policymakers find themselves forced to take action.

Saudi Arabia serves to illustrate. Beginning in the 1970s, the government of Saudi Arabia began subsidizing wheat production as a means to promote food security and became a net exporter of wheat in 1984/1985. By the mid-1990s, surpluses were so large that they were dumped on world markets (Auty 2001, p. 82). Recognizing that wheat subsidies were responsible for consuming large amounts of water and hindering diversification of the agricultural sector, the government in 1993 dramatically scaled back its support for wheat cultivation (Elhadj 2008). Saudi Arabia reportedly plans to phase out wheat production by 2016 (Montero 2008), but existing agricultural businesses have largely shifted to other forms of agricultural production. As a result, it is not clear whether aggregate water withdrawals have declined to sustainable levels.

More significant restructuring of water demand, by restricting water allocations to the agricultural sector in time of drought, has taken place in Israel. The Israeli agriculture sector consumed $80 \%$ of total water consumption during the 1960 s and 1970 s, but was reduced to $56 \%$ in 2008 due to the overall decrease water availability. This shift was associated with an overall reduction of agricultural activity, increased conservation by using advanced irrigation methods such as drip irrigation, and the increasing proportion of recycled wastewater through the Dan Region Reclamation Project (Israeli Water Authority; http://www.water.gov.il).

MENA countries with significant rain-fed agricultural sectors have faced more difficulty in adapting to prolonged, severe drought. Syria supported the near doubling of irrigated agriculture between 1985 and 2003 in the name of food security (Bazza and Najib 2003, p. 8). This strategy depleted groundwater reserves and extended agricultural cultivation into marginal areas. Faced with significantly low rainfall in 2008-2009, the Syrian government attempted to scale back the cultivation of cotton for export (Brown and Crawford 2009), but has not embarked on more significant adaptive measures.

\subsection{Water pricing}

International institutions such as the World Bank often recommend pricing water used in agriculture. While countries can reduce indirect incentives for water consumption, such as subsidies on diesel fuel for pumping, it is impractical to directly price agricultural water for small-scale users in most countries of the MENA for both political and economic reasons. First, irrigation water is already indirectly priced, capitalized in the relatively high costs of agricultural land in areas such as the Nile Delta (Richards 2002). Second, in the Delta irrigation system, farmers pay to lift water from state-owned distribution canals to privately-owned tertiary canals using 
diesel pumps, a deliberate design choice on the part of the irrigation ministry to limit excess water consumption. Third, pricing water based on consumption would require on-demand irrigation technologies that do not exist in the MENA, as well as up-front, lump investments that are out of reach for most MENA governments.

In addition, however, the assumptions behind the recommendation to price agricultural water are often problematic. Many analysts assume that this would promote on-farm water savings and that the funds collected by water pricing would be returned to farmers as a public good in improving irrigation deliveries. However, most small-scale farmers cannot afford to move from basin to drip irrigation and other 'conserving' technologies, and states would thus have to significantly invest in rural infrastructure. There is also little evidence to suggest that revenues derived from the rural sector have been adequately returned to the countryside. Further, removal of water subsidies in countries such as Morocco could hurt the poor further and increase poverty (World Bank 2007, p. 84). Charging water for larger agribusiness holdings, however, has barely been explored in the MENA.

\section{Social mobilization and water-related climate change Adaptation in MENA}

Limited space for social and political mobilization in the environmental sphere in the MENA region contributes to the governments' focus on technological solutions to increase supply rather than addressing water quality and equity issues more directly. ${ }^{17}$ As one author noted, "the degree of popular mobilization defines the cost of doing nothing" (Molle and Berkoff 2006, p. 23). In the past few years, however, there has been a significant increase in climate adaptation activities among international organizations, universities, and networks of national and regional nongovernmental organizations. These organizations have sought to raise the issue of climate change to policymakers and the public, focusing especially the linkages between climate change, water, and health.

Several regional networks have sponsored workshops, reports, public information campaigns, and worked with donors to develop adaptation projects. These include the Arab Integrated Water Resources Management Network (AWARENET), the Arab Network for Environment and Development (RAED), and the Arab NGO Network for Development (ANND; Assaf 2008). The American University of Beirut has hosted a series of workshops to bring climate scientists from different parts of the Middle East together, and begun compiling a regional research database. The goal is to facilitate informed outreach to policymakers in Lebanon and elsewhere. ${ }^{18}$ Formal regional organizations have also begun to take interest: the Arab Leagues has established a committee on climate change and held several working meetings (ESCWA 2008).

\footnotetext{
${ }^{17}$ Outside of Israel that has a more robust environmental movement, the World Bank (2007, Table 2.5) summarizes the strength of environmental NGOs in region. Morocco is considered to have the most active environmental organizations whereas the Gulf states are home to the least active environmental organizations.

${ }^{18}$ JS Personal comm. with Rami Khouri, Director, Issam Fares Institute of Public Policy, American University of Beirut, October 31, 2009.
} 
These regional networks and forums have produced a common set of prescriptions for climate adaptation across sectors including water resources. These include the establishment or expansion of early warning systems to monitor variability in precipitation and surface flows; national units and committees dedicated to climate adaptation, identification of areas under threat from desertification, and national disaster planning; undertaking national vulnerability assessments, and preparing action plans to access international and local funds for adaptation (Fayyad 2009; Mimi et al. 2009).

Regional expert networking has been fostered in part by international and regional donor agencies that increasingly support climate adaptation activities. Since the Kyoto Protocol reporting requirements and funding mechanisms (notably the CDM, clean development mechanism) initially focused on mitigation, the MENA countries did likewise. They designated national reporting units, began conducting greenhouse gas emissions inventories, and prepared projects for CDM funding. As international institutions have increasingly embraced adaptation activities, through such mechanisms as the Least Developed Country Fund at the Global Environmental Facility, some MENA countries have begun to formulate adaptation strategies and funding requests. With UNFCC assistance, Sudan (June 2007) and Yemen (April 2009) formally submitted National Adaptation Programmes of Action. ${ }^{19}$ WHO and UNDP have jointly developed the Special Climate Change Fund (SCCF) funded "Adaptation to Protect Health" project. FAO supports efficient use of water in farming and the development of Jordan's national drought mitigation strategy (http://sdnhq.undp.org/opas/en/proposals/suitable/142).

New forms of media and communications are also increasingly focusing on issues of climate adaptation and water. The rapid expansion in access to international and regional satellite networks has provided some coverage of climate change and adaptation issues. Al Jazeera, in particular, pioneered climate coverage to the Arabic-speaking populations in its talk shows, documentaries, and expert interviews; other regional satellite stations, such as Al Arabiyya and LBC, have begun to follow suit (Assaf 2008).

Community participation in climate change adaptation initiatives, however, is constrained by the broader political context. With some exceptions, communitybased environmental organizations are tolerated to the extent that they focus on a narrow range of issues. When they expand their focus to include demands for rights or accountability, they quickly encounter the array of legal restrictions and outright coercive tactics applied to contain civil society more broadly. Government restrictions on civil society can have concrete costs in terms of international assistance for climate adaptation. The Syrian government's refusal to empower local social organizations has contributed to growing resistance on the part of international organizations to render drought relief (Akkad 2009). Despite restrictions, the number of environmental organizations has been increasing, and localized protest around environmental issues, particularly pollution, is on the rise (Hopkins et al. 2001; Elmusa and Sowers 2009).

\footnotetext{
${ }^{19} \mathrm{http}: / /$ unfccc.int/cooperation_support/least_developed_countries_portal/ldc_work_programme_ and_napa/items/4722.php
} 
While popular environmental activism remains constrained in most countries of the region, other groups theoretically wield more political clout. Businesses associated with tourism are beginning to express concern about how climate change could affect the industry (World Bank 2007). In Egypt, however, tourism operators concerned about environmental issues are more focused on the immediate destruction of coral reefs and desert habitats brought about by unrestricted development than the challenges of climate change (Sowers 2007).

Little state support is evident yet for local-level adaptive water supply and quality projects that could be widely replicated, although some donors are actively working in this area. In Egypt, several NGOs have formed to pursue pilot projects in solar desalination, rainwater harvesting, and other small-scale renewable energy projects. So far, they have encountered little assistance from the government and rely almost entirely on their own resources or funds from international donors. ${ }^{20}$

\section{Addressing the population question}

The population question is perhaps the most sensitive issue for countries in MENA for religious, cultural, ideological, and security reasons. In Israel, religious leaders encourage large families, and the state has promulgated public policies that not only sanctify but monetarily reward childbirth. In particular, families with large numbers of children receive numerous subsidies and tax breaks (Tal 2002). The Environmental Ministry, furthermore, has "been unwilling to define overpopulation as an environmental priority" (Tal 2002, p. 424). A consensus exists in Israel that there are limits to any population debate and the discussion that does take place is framed as one of "development" (Orenstein 2004).

In the Arab countries, political leaderships remain ambivalent about the most appropriate ways to address population growth. While reports on the regional water situation and country environmental reports typically mention the impact of population on water resources (e.g. Sa'id 2004; Khalil 1998; Wizarat al-Dawla li Shu'un Al-Bi'ah 2007) there are no substantive linkages in practice between environmental initiatives and population initiatives. Because of domestic politics in some donor countries, major donors to the MENA region, such as USAID, have also avoided any linkages between population and environment.

In the poorer countries of MENA, education and employment for women remain the two most important avenues for reducing high rates of population growth. Women's formal participation in the labor force varies widely across the MENA, with the Gulf states showing the lowest rates of female labor force participation with the exception of Kuwait (Richards and Waterbury 2008). Not surprisingly, the Gulf countries thus have population growth rates at odd with their levels of income. In poorer countries, privatization and contraction of state-owned enterprises have disproportionately hit women's employment, as public sector jobs remain one of the more accepted and respected places for women to work (Moghadam 1997). The

${ }^{20}$ JS Interview, NGO founder, Cairo, (November 2008). 
donor-sponsored discourse on gender and environment, however, remains narrowly focused on increasing women's voices as 'stakeholders' in specific projects, rather than linking progress on female education and employment to climate adaptation.

\section{Conclusions}

Worsening drought conditions compounded by increasing demand for water and a crisis in water quality are forcing the MENA countries, including the energy-rich Arabian Peninsula, to begin to consider costly measures to confront the effects of climate change. Common policy prescriptions are emerging based on the diffusion of new water management paradigms, fostered by expert networks, international institutions, and donor agencies. However, many of these approaches are only generically formulated, and do not take into account the difficult political and social trade-offs that will be entailed in reconfiguring water policies to enhance adaptive capacities. We have sought to provide a survey of the socio-political challenges facing the MENA countries as they begin to adapt to the effects of climate change on their groundwater and surface water resources. Most countries have continued to emphasize large-scale, technical solutions for increasing supply from alternative water sources rather than to implement water conservation.

Significant policy changes in demand management have, in some cases, been facilitated by crisis conditions. These have included prolonged drought in Israel, rapidly depleting groundwater reserves in Saudi Arabia, and severe water shortages in Jordan. Crisis, however, can also produce severe disruption to livelihoods, particularly in rural areas. In eastern Syria, prolonged drought (2006-2009) without effective interventions has affected 1.3 million people; the loss of the 2008 harvest has accelerated migration to urban areas and increased levels of extreme poverty (UN $2009,1,12) .^{21}$

For the MENA countries to address adequately declining agricultural outputs and urban water shortages, however, leaders will have to not only rely upon these technical solutions but also engage societal actors in climate change adaptation, especially concerning the role of civil society and population growth. The growth of regional networks and forums along with adaptation projects funded by international institutions have begun to broaden awareness and participation in climate change adaptation for the water sector. A primary challenge, however, remains convincing political leaderships of the urgent need to prioritize adaptation measures.

Acknowledgements The authors thank Allison Herren for research assistance and Trevor Mauck for citation assistance.

\footnotetext{
${ }^{21}$ According to the UN (2009, 1), between 40,000-60,000 families have migrated in response to the drought. Here too, in the absence of a well-developed NGO network, the UN has proposed a shortterm drought assistance program.
} 


\section{References}

Abderrahman WA (2001) Water demand management in Saudi Arabia. In: Faruqui NI, Biswas AK, Bino MJ (eds) Water management in Islam. IDRC, Ottawa and UNU Press, Tokyo

Achthoven TV, Merabet Z, Shalaby K, Van Steenbergen F (2004) Balancing productivity and environmental pressure in Egypt. Agriculture and Rural Development Working Paper No 13, World Bank

Adger WN (2003) Social capital, collective action, and adaptation to climate change. Econ Geogr 79(4):387-404

Adger WN, Huq S, Brown K, Conway D, Hulme M (2003) Adaptation to climate change in the developing world. Prog Dev Stud 3(3):179-195

Akkad D (2009) Severe drought affects 1.3 million in Syria. Christ Sci Monit, 18 September, p 6

Al-Kharabsheh A (2000) Ground-water modelling and long-term management of the Azraq basin as an example of arid area conditions (Jordan). J Arid Environ 44(2):143-153

Allan JA (1997) Virtual water: a long term solution for water short Middle Eastern economies? Occasional Paper 3, School of Oriental and African Studies (SOAS), University of London

Allan JA (2001) The Middle East water question: hydropolitics and the global economy. I.B. Tauris, London

Alpert P, Krichak SO, Shafir H, Haim D, Osetinsky I (2008) Climatic trends to extremes employing regional modeling and statistical interpretation over the Eastern Mediterranean. Glob Planet Change 63:163-170

Arnell NW (1999) Climate change and global water resources. Glob Environ Change 9:S31-S49

Assaf H (2008) Climate change in the Levant and North Africa region: an assessment of implications for water resources, regional state of awareness and preparedness, and the road ahead. Presented at the climate change, water and, the policy-making process in the Levant and North Africa, Issam Fares Institute, American University of Beirut, 4 August 2009

Auty RM (2001) The political state and the management of mineral rents in capital surplus economies: Botswana and Saudi Arabia. Resour Policy 27:77-86

Ayeb H (2002) Hydraulic politics: the Nile and Egypt's water use: a crisis for the twenty first century? In: Bush R (ed) Counter-revolution in Egypt's countryside. Zed Books, London

Bajjali W, Al-Hadidi K (2005) Hydrochemical evaluation of groundwater in Azraq Basin, Jordan using environmental isotopes and GIS techniques. In: 25th annual ESRI international user conference, San Diego, California, 25-29 July 2005. http://events.esri.com/uc/2005/papers/ index.cfm

Bazza M, Najib R (2003) Towards improved water demand management in agriculture in the Syrian Arab Republic. FAO: first national symposium on management and rationalization of water resources use in agriculture organized by the University of Damascus, 28-29 April

Bouchaou L, Michelot JL, Vengosh A, Hsissou Y, Qurtobi M, Gaye CB, Bullen TD, Zuppi GM (2008) Application of multiple isotopic and geochemical tracers for investigation of recharge, salinization, and residence time of water in the Souss-Massa aquifer, Southwest of Morocco. J Hydrol 352:267-287

Bou-Zeid E, El Fadel M (2002) Climate change and water resources in Lebanon and the Middle East. J Water Resour Plan Manage 128:343-355

Brown O, Crawford A (2009) Rising temperatures, rising tensions climate change and the risk of violent conflict in the Middle East. International Institute for Sustainable Development

Center for Environment and Development in the Arab World (CEDARE) (2005) Status of integrated water resources management in the Arab Region. UNDP and the Arab Water Council, Cairo

Cline R (2007) Global warming and agriculture: impact estimates by country. Peterson Institute for International Economics, Washington DC

Conway D (2005) From headwater tributaries to international river: observing and adapting to climate variability and change in the Nile Basin. Glob Environ Change 15(2):99-114

Conway D, Hulme M (1996) The impacts of climate variability and climate change in the Nile Basin on future water resources in Egypt. Water Resour Dev 12(3):277-296

Cullen H, Haggard S, Magaloni B (2009) Grievance and opportunity: food prices, political regime, and protest. Paper presented at the international studies association's annual meeting, New York, NY, 15 February

Das Gupta S, LaPlante B, Meisner C, Yan J (2007) Impact of sea level rise on developing countries: a comparative study. Policy Res Work Pap 4136. World Bank, Washington, DC 
De Rosa DA (1997) Agricultural trade and rural development in the Middle East and North Africa: recent developments and North Africa. Policy Res Work Pap 1732. World Bank, Washington, $\mathrm{DC}$

De-Shalit A (1995) From the political to the objective: the dialectics of zionism and the environment. Environ Pol 4(1):70-87

Dietz T, Ostrom E, Stern PC (2003) The struggle to govern the commons. Science 302:1907-1912

Economist (2008) Buying the farm: Saudi Arabia. Econ 388(8594):39

Economist (2009a) Green shoots. Econ 390(8623):67-68

Economist (2009b) Petrodollars v smallholders. Econ 391(8628):48

Economic and Social Commission for Western Asia (2008) Climate change in ESCWA region: reasons for concern, Arab league meeting, Damascus, Syria, 13-15 April 2008

Egyptian Environmental Affairs Agency (1999) Initial national communication on climate change for the United Nations framework convention on climate change. Cairo

Eid H, El-Marsafawy SM, Ouda SA (2007) Assessing the economic impacts of climate change on agriculture in Egypt. Pol Res Work Pap. The World Bank, Washington, DC

Elarabawy M, Tosswell P (1998) An appraisal of the Southern Valley Development Project in Egypt. J Water Supply Res Technol AQUA 47(4):167-185

Elarabawy M, Attia B et al (2000) Integrated water resources management for Egypt. J Water Supply Res Technol AQUA 49(3):111-125

Elhadj E (2008) Saudi Arabia's agricultural project: from dust to dust. Middle East Rev Int Aff 12(2):29-37

Elmusa S, Sowers J (2009) Damietta mobilizes for its environment. Middle East Report Online. http://www.merip.org/mero/mero102109.html. Accessed 21 October 2009

El Raey M (2008) Impact of climate change on the Nile Delta region. Paper presented at climate change in Egypt conference, Cairo, 11 November

Evans P (1996) State-society synergy. University of California Press, Berkeley

Evans G (2008a) Conflict potential in a world of climate change. Address to Bucerius Summer School on Global Governance Berlin, 29 August

Evans JP (2008b) 21st century climate change in the Middle East. Clim Change 92:417-432

Evans JP (2009) Global warming impact on the dominant precipitation processes in the Middle East. Theor Appl Climatol, Published online 19 May

Fahmy N (2002) Politics of Egypt: state-society relationship. Routledge, New York

Falkenmark M (1986) Fresh water-time for a modified approach. Ambio 15(4):192-200

Farber E, Vengosh A, Gavrieli I, Marie A, Bullen TD, Mayer B, Holtzman R, Segal M, Shavit U (2004) The origin and mechanisms of salinization of the Lower Jordan River. Geochim Cosmochim Acta 68:1989-2006

Fayyad M (2009) Current status of climate change research and policy in the Levant. Presented at "Climate change, water and the policy-making process in the Levant and North Africa," American University of Beirut, Beirut, Lebanon, 4 August 2009

Fischhendler I (2008) Institutional conditions for IWRM: the Israeli case. Ground Water 46(1):91102

Food and Agriculture Organization (2005) Fertilizer use in Egypt. http://www.fao.org/docrep/ 008/y5863e/y5863e00.HTM

Ford N (2003) Tapping into Libyan resources. Middle East 332:50

Gao X, Giorgi F (2008) Increased aridity in the Mediterranean region under greenhouse gas forcing estimated from high resolution simulations with a regional climate model. Glob Planet Change 62:195-209

GLOWA (2009) GLOWA Jordan River, phase II final report: an integrated approach to sustainable management of water resources under global change. http://download.glowa-jordan-river. com/GLOWAJR_report_phaseII.pdf

Gorenflo A, Brusilovsky M, Faigon M, Liberman B (2007) High pH operation in seawater reverse osmosis permeate: first results from the world's largest SWRO plant in Ashkelon. Desalination 203:82-90

Gvirtzman H, Garven G, Gvirtzman G (1997) Hydrogeological modeling of the saline hot springs at the Sea of Galilee, Israel. Water Res Res 33(5):913-926

Hopkins N, Mehanna S, el Haggar S (2001) People and pollution: cultural constructions and social action in Egypt. American University in Cairo Press, Cairo, Egypt

Inbar Y (2007) New standards for treated wastewater reuse in Israel. Wastewater reuse-risk assessment, decision-making and environmental security. NATO Security through Science Series. Springer, The Netherlands, pp 291-296 
IPCC (2007) Climate change 2007: the physical science basis. In: Solomon S, Qin D, Manning M, Chen Z, Marquis M, Averyt KB, Tignor M, Miller HL (eds) Contribution of working group I to the fourth assessment report of the Intergovernmental Panel on Climate Change. Cambridge University Press, Cambridge and New York

Jaber JO, Mohsen MS (2001) Evaluation of non-conventional water resources supply in Jordan. Desalination 136:83-92

Kandil HM (2003) Institutional reform vision for the irrigation sector in Egypt. Water Resour Dev 19(2):221-231

Kasinof L (2009) At heart of Yemen's conflicts: water crisis. Christ Sci Monit, 5 November, p 6

Kassem M (2004) Egyptian politics: the dynamics of authoritarian rule. Lynne Rienner Publishers, Boulder

Khalil M (1998) Azmat al-miyah fi al-Sharq al-Awsat wa-al-amn al-qawmi al-'Arabi wa al-Misri (The water crisis in the Middle East and Arab and Egyptian National Security). al-Tab ah 1. ed. alMaktabah al-Akadimiyah, al-Qahirah

Kreimer A, Arnold M, Carlin A (2003) Building safer cities: the future of disaster risk. World Bank, Washington, DC

Kronenberg G (2004) The largest SWRO plant in the world-Ashkelon 100 million m(3)/y BOT project. Desalination 166:457-463

Lahav O, Birnhack L (2007) Quality criteria for desalinated water following post-treatment. Desalination 207:286-303

Lemos MC, Agrawal A (2006) Environmental governance. Annu Rev Environ Resour 31:297325

Lloyd JW, Pim RH (1990) The hydrogeology and groundwater resources development of the Cambro-Ordovician sandstone aquifer in Saudi Arabia and Jordan. J Hydrol 121:1-20

Marie A, Vengosh A (2001) Sources of salinity in groundwater from Jericho area, Jordan valley. Ground Water 39:240-248

Mashru` al-nahr al-sina`i al-`azim (The Great Man-Made River Project) (1989) [Tripoli]: Jihaz Tanfidh wa-Idarat Mashru` al-nahr al-Sina`i al-Azim, Amanat al-Lajnah al Sha`biyah al`Ammah lil-Istislah al Zira`i wa-Ta`mir al-Aradi, Libya: Tripoli

Miller JE (2003) Review of water resources and desalination technologies. Sandia National Laboratories, Albuquerque, NM

Milly PCD, Dunne KA, Vecchia AV (2005) Global pattern of trends in stream flow and water availability in a changing climate. Nature 438:347-350

Mimi Z, Mason M, Zeitoun M (2009) Climate change: impacts, adaptations and policy-making process: Palestine as a case study, Presented at "climate change, water, and the policy-making process in the Levant and North Africa," American University of Beirut, Beirut, Lebanon, 4 August 2009

Ministry of Public Works and Water Resources, Arab Republic of Egypt (2005) Integrated water resources management plan

Moghadam V (1997) Economic liberalization, women and politics. Middle East Policy September:164-166

Mohorjy AM, Grigg NS (1995) Water-resources management system for Saudi Arabia. Water Resour Plan Manag 121(2):205

Mohsen MS (2007) Water strategies and potential of desalination in Jordan. Desalination 203:27-46

Molle F, Berkhoff J (2006) Cities versus agriculture: revisiting intersectoral water transfers: potential gains and conflicts. Comprehensive Assessment Research Report 10. Comprehensive Assessment Secretariat, Colombo, Sri Lanka

Montero D (2008) Insecurity drives farm purchases abroad. Christ Sci Monit 101(19):1-11

Nelson DR, Adger WN, Brown K (2007) Adaptation to environmental change: contributions of a resilience framework. Annu Rev Environ Resour 32:395-419

Orenstein DE (2004) Population growth and environmental impact: ideology and academic discourse in Israel. Popul Environ 26(1):41-60

Oroud IM (2008) The impacts of climate change on water resources in Jordan. In: Zereini F, Hotzl $\mathrm{H}$ (eds) Climate changes and water resources in the Middle East and North Africa. Springer, Environmental Science and Engineering, Berlin

Ostrom E (1990) Governing the commons: the evolution of institutions for collective action. Cambridge University Press, Cambridge

Ostrom E (1992) Crafting institutions for self-governing irrigation systems. ICS Press, San Francisco

Pelling M, High C (2005) Understanding adaptation: what can social capital offer assessments of adaptive capacity? Glob Environ Change 15:308-319 
Richards A (2002) Coping with water scarcity: the governance challenge. Institute on Global Conflict and Cooperation, Policy Papers. http://repositories.cdlib.org/igcc/PP/PP54

Richards A, Waterbury J (2008) A political economy of the Middle East, 3rd edn. Westview, Boulder, $\mathrm{CO}$

Rimawi O, Al-Ansari NA (1997) Groundwater degradation in the northeastern part of Mafraq area, Jordan. Freshwater contamination (Proceedings of rabat symposium S4, April-May 1997). IAHS Publ 243:235-243

Ronayne M (2005) The cultural and environmental impacts of large dams in Southeast Turkey. Factfinding Mission Report. National University of Ireland, Galway, and the Kurdish Human Rights Project, London

Sa id R (2004) Azmat al-miyah fi al-watan al-Arabi (The water crisis in the Arab countries). alTab`ah 1. ed. Dar al-Amin, al-Qahirah

Salem M (2005) Project Toshka on the edge of failure. Al Masry Al Yom, 23 April

Sánchez E, Gallardoa C, Gaertner MA, Arribas A, Castro M (2004) Future climate extreme events in the Mediterranean simulated by a regional climate model: a first approach. Glob Planet Change 44:163-180

Sauvet-Goichon B (2007) Ashkelon desalination plant-a successful challenge. Desalination 203:75-81

Shahin M (1996) Hydrology and scarcity of water resources in the Arab Region. A.A. Balkema, Rotterdam, The Netherlands

Smit B, Wandel J (2006) Adaptation, adaptive capacity and vulnerability. Glob Environ Change $16: 282-292$

Sowers J (2007) Nature reserves and authoritarian rule in Egypt: embedded autonomy revisited. J Environ Dev 16(4):375-397

Sowers J (forthcoming a) Institutional change and environmental governance in the Middle East: water and authority in Egypt. In: VanDeveer S, Steinberg P (eds) Comparative Environmental Politics. MIT Press, Cambridge

Sowers $\mathbf{J}$ (forthcoming b) Re-mapping the nation, critiquing the state: narrating land reclamation for Egypt's New Valley. In: Davis DK, Burke E (eds) Environmental imaginaries of the Middle East: history, policy, power, and practice. Ohio University Press, Athens

Suppan P, Kunstmann H, Heckel A, Rimmer A (2008) Impact of climate change on water availability in the Near East. In: Zereini F, Hotzl H (eds) Climate changes and water resources in the Middle East and North Africa. Springer, Environmental Science and Engineering, Berlin

Steinberger EH, Gazit-Yaari N (1996) Recent changes in the spatial distribution of annual precipitation in Israel. J Climate 9:3328-3336

Stern N (2006) Stern review: the economics of climate change. http://www.hm-treasury.gov.uk/ stern_review_report.htm

Tal A (2002) Pollution in a promised land. University of California Press, Berkeley

Tantawi A (1990) Mawarid al-miyah fi Libiya (Water resources in Libya). al-Tab`ah 1. ed. [Cairo]: al-Maktab al-Misri li-Tawzi` al-Matbu’at

Tolba MK, Saab N (2008) Arab public opinion and the environment conference report of 18 country survey. http://www.afedonline.org/en/inner.aspx? contentID=88. Accessed 9 May 2009

Trottier J (2000) Water and the challenge of Palestinian institution building. J Palest Stud 29(2):3550

United Nations (2009) Syria drought response plan

UNDP (2006) Human development report 2006. Beyond scarcity: power, poverty and the global water crisis. UNDP, New York

UNDP (2007/2008) Human development report 2007/2008, fighting climate change: human solidarity in a divided world. UNDP, New York

UNEP (2003) Desk study on the environment in the occupied Palestinian Territories. UNEP PCDMB, Geneva

Vengosh A (2003) Salinization and saline environments. In: Lollar BS (ed) Environmental geochemistry. Treatise in geochemistry, vol 9. Executive Editors: Holland HD, Turekian KT, Elsevier Science. http://www.TreatiseOnGeochemistry.com

Vengosh A, Rosenthal A (1994) Saline groundwater in Israel: its bearing on the water crisis in the country. J Hydrol 156:389-430

Vengosh A, Heumann KG, Juraske S, Kasher R (1994) Boron isotope application for tracing sources of contamination in groundwater. Environ Sci Technol 28:1968-1974

Vengosh A, Spivack AJ, Artzi Y, Ayalon A (1999) Boron, strontium, and oxygen isotopic and geochemical constraints for the origin of salinity in groundwater from the Mediterranean coast of Israel. Water Resour Res 35:877-1894 
Vengosh A, Kloppmann W, Marie A, Livshitz Y, Gutierrez A, Banna M, Guerrot C, Pankratov I, Ranan H (2005) Sources of salinity and boron in the Gaza Strip: natural contaminant flow in the southern Mediterranean Coastal aquifer. Water Resour Res 41:W01013

Vengosh A, Hirschfeld D, Vinson DS, Dwyer GS, Raanan H, Rimawi O, Al-Zoubi A, Akkawi E, Marie A, Haquin G, Zaarur S, Ganor J (2009) High naturally occurring radioactivity in fossil groundwater in the Middle East. Environ Sci Technol 43(6):1769-1775

Vörösmarty CJ, Green P, Salisbury J, Lammers RB (2000) Global water resources: vulnerability from climate change and population growth. Science 289:284-288

Waldoks EH (2009) A man-made disaster. Jerusalem Post, January 29. http://www.jpost.com/Home/ Article.. aspx? $\mathrm{id}=131030$

Warner J (2008) Contested hydrohegemony: hydraulic control and security in Turkey. Water Altern 1(2):271-288

Weinthal E (2002) State making and environmental cooperation: linking domestic and international politics in Central Asia. MIT Press, Cambridge

Weinthal E, Marei A (2002) One resource two visions: the prospects for Israeli Palestinian water cooperation. Water Int 27(4):1-8

Weinthal E, Vengosh A, Marie A, Gutierrez A, Kloppmann W (2005) The water crisis in the Gaza strip: prospects for remediation. Ground Water 43:653-660

Wizarat al-Dawla li Shu'un Al-Bi'ah (2007) Al-Taqriir Al-Senawi li Wizarat al-Dawla li Shu'un AlBi'ah (Annual report of the ministry of state for environmental affairs). Ministry of State for Environmental Affairs, Egypt, Al-Qahirah

World Bank (2007) Making the most of scarcity: accountability for better water management results in the Middle East and North Africa. World Bank, Washington, DC

Zhang X, Aguilar E, Sensoy S, Melkonyan H, Tagiyeva U, Ahmed N, Kutaladze N, Rahimzadeh F, Taghipour T, Hantosh TH, Albert P, Semawi M, Ali MK, Al Shabibi MHS, Zaid Al-Oulan Z, Zatari T, Khelet IAD, Hamoud S, Sagir R, Demircan M, Eken M, Adiguzel M, Alexander L, Peterson TC, Wallis T (2005) Trends in Middle East climate extreme indices from 1950 to 2003. J Geophys Res 110:D22104 